\title{
Aligning policy ideas and power: the roots of the competitiveness frame in European education policy
}

\begin{abstract}
How and why do some ideas attain agenda status while others do not? This paper seeks to explore these questions in the context of the policy changes observed in the evolution of European education policy. By drawing from the literature on agenda-setting and employing process tracing, the paper develops a theoretical argument to investigate the causal mechanisms through which a new problem definition is set. The central argument is that three factors affect the way in which a specific problem definition wins over another: (i) the presence of a policy entrepreneur; (ii) the ability to construct a convincing narrative to support a particular interpretation of a problem; and (iii) the specific zeitgeist of a given period, namely the social and political context within which ideas gain ground. The paper contributes to the literature on European education policy by examining how specific (economic) ideas about education emerged. It also contributes to the theoretical debate on agenda studies and how policy problems are set.
\end{abstract}

Keywords: policy entrepreneurs; ideas; agenda-setting; European education policy; policy change

\section{Introduction}

Despite the lack of legal competences and the saliency of education in Member States as a policy field closely linked to nation-building processes (Bartolini 2005), the European Commission has significantly transformed its education policy since the launch of the Lisbon Strategy in 2000 (Walkenhorst 2008). The goal of making Europe "the most competitive and dynamic knowledge-based economy in the world" (European Council 2000) has placed education at the heart of European strategies for achieving growth and improving economic performance (Chou and Gornitzka 2014). With the post-Lisbon agenda "Europe 2020", the European Commission has remarkably increased its role in terms of promoting a policy agenda in which the economic dimension of education, intended as a tool to provide people with adequate skills for labour market needs and to improve economic growth, prevails over other dimensions such as education as a tool for personal development and social inclusion (Holford and Špolar 2012). These policy goals, which put a strong emphasis on the role of education "in preparing nations to compete in the global knowledge economy" (Auld and Morris, 2016 : 203) have been codified at European level in a new policy mode of cooperation, the Open Method of Coordination (OMC). 
The OMC is a governance template which aims to: (i) identify and define common goals to be accomplished by specific deadlines; (ii) establish indicators and benchmarks around these common goals; (iii) formulate common objectives to be adapted in the national context, and (iv) periodically monitor and peer review (Gornitzka 2005). Although the OMC is wrapped in the legal burden of subsidiarity and is based on voluntary cooperation among Member States, it has expanded the role of the European Commission in the formulation of a cognitive, normative and regulative 'model' of European education policy through influential guidelines and recommendations (Jakobi et al. 2010).

While a growing strand of research is investigating the implications and consequences of these developments through the formation of "a European space of education" (Grek et al. 2013; Borras, 2009), the question of how specific ideas about education intervened in the European policymaking process has only been partially addressed by the literature. This paper attempts to fill this gap by explaining why and how a set of ideas about education became predominant at the European level. This question is also particularly relevant at a theoretical level, given the peculiarities of education as a policy field characterised by weak legal supranational competences, issue complexity - given different purposes for education in life and work - and institutional complexity, with multiple actors having overlapping competences and policy agendas (Zahariadis 2008). In this respect, even though a functionalist perspective relying on mutual interdependence across States and the consequent pressures for integration (Rosamond 1999) could be useful in explaining why the OMC is a preferred policy mode - for example as a solution to the "common structural" problem of increased global competition for which knowledge is lacking on the national level - it fails to specify how the consensus around the common problem, and among multiple actors with divergent preferences, was created. Within this issue and institutional complexity, the paper suggests that an ideational explanation that takes into account how policy actors do interact with ideas is better analytically equipped to capture some aspects of the puzzle regarding policy change in education.

By drawing on the agenda-setting literature and process tracing the policy developments of European education policy between 1975 and 1997, the paper analyses how the idea of education policy as a contributor to European competitiveness was constructed. The paper also joins a growing body of literature that examines the intersection between ideas and power in public policies by detailing the causal mechanisms through which policy problems are set (Béland and Cox 2016). In particular, the paper highlights how three factors affect the way in which a specific problem definition wins over another: (i) 
the presence of a central policy entrepreneur with power and resources; (ii) the ability to construct a convincing narrative to support a particular interpretation of a problem; and (iii) the specific zeitgeist of a given period, namely the social and political context within which ideas gain ground.

The findings seem to suggest that the European Commission acted as a skilful policy entrepreneur that was able to construct a convincing policy narrative that linked economic "problems" in the European Community and education as a potential "solution" to the political and economic survival of Europe. By anchoring education to the goals of reaching a common market, in which the mobility of workers was playing a crucial role, the European Commission was able to reach a consensus among those Member States that had always been reluctant to cede any formal power to the European Commission. Indeed, by framing education under the dual notion of a solution to the common European economic project and as a political project of common European identity, the European Commission was able to gain and mobilise support from wider constituencies, including business actors, student associations and Member States.

The paper is organised as follows. The next section reviews the literature on agenda-setting and presents the theoretical argument. Section three applies the theoretical argument to the empirical case by analysing policy debates and discourses on European education policy. The final section outlines the contribution of the article and discusses the findings.

\section{Ideas, actors and policy agendas}

That ideas have an influence on policymaking is a claim that may appear self-evident. Explaining how they matter is a more contested issue: "There are a lot of ideas around, and there is no lacking of ideas. The real question is, which of these ideas will catch hold?" (Kingdon 1984, 81). It is precisely this question that this paper addresses; namely, how and why certain policy ideas win over other plausible ones. Elucidating how certain policy issues get to the top of the political agenda and which are to be dealt with and on what terms has attracted considerable interest from scholars of public policy (Cobb and Elder 1972, 86; Bachrach and Baratz 1962). Several studies have focused on providing an account of the dynamics through which new ideas, policy proposals and problem interpretations emerge and attract the attention of policymakers (Kingdon 1984; Princen 2011). Agenda-setting processes matter not only because an issue gains attention, but also because they specify the definition of alternatives, namely the 
alternative problem definition or the alternative solutions to the problem. In other words, agenda-setting involves a process of selection and prioritisation, which, in turn, restricts the field of ideas to only the most powerful. As Schattschneider suggests, the definition of the alternatives is the "supreme instrument of power [...] because the definition of the alternatives is the choice of conflicts, and the choice of conflicts allocates power" (Schattschneider 1960, 66). However, why and when does an issue reach the institutional agenda?

A seminal contribution on agenda-setting that emphasises why an issue makes it on to the decision agenda is the Multiple Stream Model devised by John Kingdon (1984). Kingdon's argument is that certain issues are placed on governments' decision agendas if what he identifies as the problems, the politics and the policy streams are "coupled" with clever policy entrepreneurs during "transitory" moments of opportunity, called policy windows (Zahariadis 2008). Policy entrepreneurs explain "by whom" alternatives are pushed forward. They are individuals with access, time, resources and energy who try to sell their ideas to policymakers (Zahariadis 2008, 520). Kingdon's perspective provides a useful set of categories to clarify why and when an issue gains attention; however, it also presents some limitations. Among its shortcomings is the lack of a specification of the mechanisms through which change will occur and for what reason (Mucciaroni 1992), and the lack of concern for how the social and political context impacts the shifts in the problem and solution streams over time (Weir 1992, 18).

In this paper, Kingdon's model is employed as a general framework because of the useful categories it provides. However, in order to overcome the limitations of the model, his perspective is complemented by three explanatory factors that can further elucidate why one problem definition triumphs over another. These factors - which will be discussed in detail below - are: (i) the power of the actors advocating their favourite definition, which relates to Kingdon's "policy entrepreneurs" but qualifies the strength of their power; (ii) how a problem is framed through the use of rhetorical strategies; and (iii) the social and political context within which policies operate which might favour consideration of some issues while discouraging consideration of others.

The first factor relates to the power of the actors holding a given set of ideas and entering into the policy arena as policy entrepreneurs or ideas carriers, namely policy entrepreneurs who not only implement ideas but also construct and reconstruct them (see also Schmidt and Thatcher 2013, 22). Power is conceptualised under three dimensions: the material resources that actors possess, their role as epistemic communities with recognised expertise in a particular area for which they can claim authoritative 
knowledge (Haas 1992, 3), and finally, their moral power intended as the ability to shape norms and values in influencing others' goals for action (Lukes 1974; Mehta 2011).

The second factor that impacts a winning problem definition refers to the framing of an issue through rhetorical elements. In the policy analysis literature, framing refers to the selection of, and emphasis on, particular aspects of a problem according to an evaluative or analytical criterion (Daviter 2007). Scholars consider framing to be a crucial element of an issue definition. Rein and Schoen define a frame as "a perspective from which an amorphous, ill-defined, problematic situation can be made sense of' (Rein and Schoen 1993, 146); similarly, Dryzek maintains that "each frame generally interprets the world in its own particular and partial way" (Dryzek 1993, 222); and Yanow points out that frames "highlight and contain at the same time that they exclude" (Yanow 2000,11). Therefore, a frame encompasses an interpretation of a problem, meaning that it involves judgements, visions and choices about the existing problems, their origins and possible solutions (Kingdon 1984; Rochefort and Cobb 1994). Drawing upon policy analysis studies, three rhetorical strategies that actors often use to help assign responsibility to particular sources, legitimise possible political action and challenge or protect the existing social order are considered. These strategies are measurement or counting, narratives or storytelling, and naming, blaming and claiming.

Measurement or 'counting' is a powerful strategy that is frequently used by those involved in defining a problem (Stone 2002, 33). Policy discussions often begin with the production of reports that show the magnitude of a problem using counting, which impacts the problem definition in two main ways. On the one hand, it makes people notice the problem more, thus potentially stimulating demands for change; on the other, it zooms in on a specific aspect of the problem, thus favouring some features of the issue while simultaneously ignoring others. The second strategy involves the employment of a convincing narrative or storytelling. Patterson and Monroe define a narrative as "the stories people tell to weave disparate facts together in a cognitive way to make sense of reality" (Patterson and Monroe 1998, 315). Fischer argues that "the narrative is especially geared towards the goals of the actors and the way changing goals and intentions causally contribute to social change; it seeks to comprehend and convey the direction of human affairs" (Fischer 2003, 163). Thus, a narrative provides an order and a meaning to a given situation. How are narratives constructed? As in Aesop's Fables, they have a plot, characters and settings. Events are outlined in a sequential order in an effort to coherently explain a problem's origin and development. Actors using narratives employ many rhetorical strategies including metaphors, 
synecdoche, symbolism and figurative language to aggravate a point and focus attention on it (Stone 2002). A common storyline in policy narratives is the story of decline, as synthesised by Stone: "In the beginning things were good. But they got worse, and right now they are nearly intolerable; something must be done" (Stone 2002, 158). This story usually ends with the prediction of a crisis and some sort of proposal to avoid it. Policy narratives also help to shed light on the fact that it is possible to ameliorate a situation through various proposed policy actions, usually those actions favoured by the storyteller. Proposals can even take the form of a warning that, unless some action is taken, the problem will only get worse. Finally, the third strategy is the one detected by the sociological account of Felstiner and his colleagues and is based on a three-stage process: naming, blaming and claiming. More precisely, naming refers to an "injurious experience" (Felstiner et al. 1980, 634), which is attributed "to the fault of another individual or social entity (Felstiner et al. 1980, 635). Only when naming and blaming have occurred can we expect claiming to take effect - "when someone with a grievance voices it to the person or entity believed to be responsible and asks for some remedy" (Felstiner et al. 1980, 635-636). For example, obesity in young children (naming of the problem) may be attributed to weak government policies (blaming), and thus an improvement in governmental strategies to ensure children are given the correct advice on a healthy diet may be proposed (claiming).

The third factor that impacts a winning problem definition is the fit between the problem and the broader social currents or public philosophy of the moment - the zeitgeist - which significantly increases the chances of success for the winning problem definition. Accordingly, a zeitgeist stresses the role of the social and political context within which ideas gain (or do not gain) ground, which considerably increases (or diminishes) the possibility of a specific idea succeeding. Numerous terms have been used in the literature that overlap with the concept of zeitgeist; for example, "world views" (Goldstein 1993), "wider societal concerns" (Rhinard 2010), and "national mood" (Kingdon 1984). What these terms commonly underline is that the social and political context within which policies operate favours consideration of some issues while discouraging consideration of others. For instance, Baumgartner argues that, in the EU context, neo-liberal policy solutions have a better chance of making their way to the top of the political agenda (Baumgartner 2007, 485-486). Hence, the specific definition of a problem is also influenced by the social, cultural and ideological context within which the definition of the problem takes place and, in this regard, "any complete accounting must link changes in society, politics and the intermediaries that link the two" (Mehta 2011, 40). For example, ideas such as the single European market or the Maastricht Treaty would probably have encountered strong opposition if they had been 
proposed in the 1970s, which was characterised as a period of "Eurosclerosis" that included pessimism among elites, interest groups and the public at large about European integration (Zahariadis 2008). Hence, ideas coinciding with the mood gain greater legitimacy and "currency". Contextual changes can open a policy window that policy entrepreneurs can, in turn, exploit to put an issue on the agenda. In other words, for frames to achieve a position on political agendas - and to establish policies as priorities - they need to refer to "wider societal concerns" (Rhinard 2010) and make a convincing case that a "supranational scale" is appropriate in response to the context of the problem (Leitner 1997, 124).

In the following section, this theoretical argument is applied to the empirical case of European education policy. The argument is developed through an in-depth examination of the case study involving the origins and impact of the "competitiveness" idea regarding education policy. To this end, process tracing (Bennett and Checkel 2014) is the method employed to identify the causal mechanisms and chain of events that led to the affirmation of the idea of competitiveness as the cornerstone of the European cooperation framework in education under the OMC. The analysis is based on original archival research carried out at the Archives of the European Union in Florence, involving cabinet protocols, personal correspondence, official reports - such as White Papers, Green Papers and Memoranda - meeting minutes and confidential policy documentation relating to the period 1975-1997.

\section{Setting the problem of European education policy}

At the initial stage of the European integration process, the political interest in education was rather limited, with the main purpose of the Community being geared towards the implementation of a customs union and a common agricultural policy (Lawn 2002). Indeed, Article 128 of the Treaty of Rome made no provisions for education, while instead referring to the drawing up of general principles for vocational training with a view to facilitating the free movement of workers and implementing the four market freedoms (European Commission 1989). However, the lack of economic interest was not the only reason why education was barely acknowledged. An important factor was the reluctance of Member States to give up their national prerogatives for a common educational policy (Rasmussen and Knudsen 2009). Consistent with Alan Milward's thesis (1992) which posited that the European integration project was based on a European level (responsible for economic integration) and on a Member State level 
(responsible for welfare), education was strongly retained as an exclusive national competence as it was so closely linked to national cultures and to State-building processes (Bartolini 2005).

The idea of closer education policy coordination and a" European dimension of education" within the European Community had a long history going back to the 1960s (Corbett 2005). In practice, this was a history of failure given the lack of provision for education in the Treaty and the reluctance of Member States to surrender their national prerogatives in a policy field so tightly connected to the construction of national identities (De Wit and Verhoeven 2001). From the mid-1970s, European education policy gradually emerged as a policy domain on its own. In terms of institutional developments, the creation of a specific Directorate in 1973 that included education and a and a Resolution on a Community Action programme on education (Council 1976) which was advancing cooperation in European education, are all evidence of a growing interest at Community level in education (Pépin et al. 2006). Between 1975 and 1985, European education policy was characterised by the coexistence of different social and cultural aims. Two publications - the Janne Report (1973) and the paper Education in the European Community (CEC 1974) - clearly pointed to more social and cultural aspects of education. Although pursuing economic goals, such as the mobility of workers (that was acknowledged through the goal of the academic recognition of diplomas) both publications interpreted the notion of the "European dimension of education" under a genuine social and cultural dimension, as manifested by the inclusion of themes such as knowledge of foreign languages, the promotion of exchanges and cooperation between education institutions and the importance of education for migrant children. However, the European Commission was well aware of the difficulty of advancing a common education policy. Indeed, by referring to the social problems of the period, the Commissioner for Education Ralf Dahrendorf was cautiously arguing that "the Community can make only a very limited contribution to their solution, this is partly because the Community is not necessarily the appropriate political framework for solving them”. Hence, in Dahrendorf's view, the main contribution of education was "to promote the process of EU integration, for instance by increasing mutual understanding, eliminating prejudice, and promoting initiatives for cooperation between institutions from different member countries" (Corbett 2005, 81). At the same time, the institutional arrangements for educational policy were also clear. Member States regarded education as a State preserve to be jealously guarded and any Community interference was managed by reaffirming Member States’ prerogatives (Beukel 1994). 
Several developments beginning in 1985 led to a gradual shift in the policy debate on the role of education within the European integration project. One event that focused attention on education was the worsening of the economic conditions in Europe. At the start of the 1980s, and after the two 'oil shocks' of 1973 and 1979, Member States experienced an unprecedented rise in unemployment to levels not reached since the Great Depression: from 5.8 million in 1980 to 9.3 million in 1982 and then 11.2 million in 1985, with the highest rates in Belgium, Italy, France, the United Kingdom and the Netherlands (Fitoussi, Phelps, and Sachs 1986, 487). This rise in unemployment was exacerbated by the emergence of wholly new products, processes and industries with new competitors appearing on the international scene, pointing to the need for a well-trained workforce (Cusumano 1985, 264-265). These changes in the structural conditions moved new policy issues about the role of education on to the political agenda: the turn from a Taylorist-Fordist model to a Toyotist one not only required firms to adapt their strategies to volatile and unpredictable market conditions, it also required workers to upgrade their skill sets (Boyer 1988). Moreover, in the opinion of the then Director for Education, Training and Youth Policy Hywel Ceri Jones in 1983, "unemployment and the need for a more active European-wide strategy for innovation in the field of technology have become the central point on the agenda of the community's domestic preoccupations" (Jones 1983, para 6). Jones's calculation suggests that the year 1983 can thus be the starting point for a new discourse on education, parallel to the social one, whereby the concept of modernising European economies became a major concern in the European Commission's educational debate.

The presidency of Jacques Delors opened a new phase of expansion for the European Commission in the education domain. When announcing his work programme to the European Parliament in January 1985, Delors stressed the need to reinforce Europe's credibility by taking firm steps in three directions, which were embedded in the White Paper presented in 1985 on the path towards the Single Market: (i) encourage genuine freedom of movement; (ii) promote genuine economic convergence, and (iii) take measures towards human development in the fields of environment and culture (Agence Europe 1985). To meet the goals of the Single Market project, the reinforcement of the scientific and technological basis of European industry and the promotion of its international competitiveness were considered crucial factors (CEC1987). In Neave's view, “whatever their precise consequences for education, industry and society (and the consensus is far from being established here), the new high technological revolution that stands in the offing is seen as the key to the economic status and fortune of nations" (Neave 1988, 7). A 
strong supporter of the economic relevance of education and training policies, Delors firmly believed that the Single Market project required a qualified manpower which would be able to move across the EU and have their educational credentials recognised in all Member States of the European Community. Nevertheless, the link between education and new technologies was not the only scope foreseen. Education also had to serve the ideological dimension underpinning the European project by reinforcing the feeling of belonging to the same community, enriched by its differences. Accordingly, if the European Community was to succeed as an entity, cultural integration was a must, with education being considered as the glue to bind the Member States together and a way to give a "human face to the Community" (Corbett 2005, 115).

In addition to the political entrepreneurship of Delors, another relevant personality who strongly advocated the implementation of education and training interventions to support the economic strategies of the European Community was Peter Sutherland, an Irish businessman and former Attorney General of Ireland. In 1985, Sutherland became the member of the Commission responsible for the General Directorate for Social Affairs, Education and Employment. Though aware of the difficulties involved in creating "a common European idea about education", he nevertheless considered investment in education to be the necessary condition for building a single market that was technologically advanced and internationally competitive. When opening a meeting with social partners in January 1985 in Val Duchesse, Sutherland declared: "We are all of us in this room fully committed to the re-emergence of Europe as a major first-class industrial power [...] we must transform - together - our whole approach to education" (Sutherland 1985a, 1). In other words, and different for instance to the cautious attitude adopted by Ralf Dahrendorf and Ivor Richard, previous Commissioners for Education always very careful not to overstep Member States' competences in education, Sutherland was a firm believer in the importance of education apropos developing human capital and promoting Europe's growth (Sutherland 1985b, 3).

This goal would have required a shift in the priorities of education policies, not only in terms of policy content but also in increasing the institutional responsibility of the European Commission. In relation to policy content, education became considered as a tool that could solve the problem of the lack of qualified human resources that European industry required to improve its technological base. For instance, the European Social Fund - one of the oldest Community instruments whose objective was to assist the most vulnerable groups and regions - was regarded by Sutherland as "the Red Cross in a time of economic 
crisis, financing a mountain of persons whose training is not matched to the requirements and opportunities of today" (Sutherland 1985c, 2), with the establishment of new objectives more closely associated with the development of new technologies. At the same time, ideas already existing in the policy debate, such as the European dimension of education and the notion of student mobility, were framed in a more economic perspective. Rather than being seen in a more cultural and social sense, mobility was instead intended to be linked more to the Single Market project with the idea of "an Italian student training in France and becoming familiar with French products and technical standards, establishing strong friendly ties with French engineers or researchers and developing the habit of thinking European first, and not American or Japanese, before making economic decisions" (Sutherland 1985d, 5). In terms of institutional responsibilities, the link made between the lack of European growth (and competitiveness) raised the agenda status of education and generated greater involvement from Member States and interest groups that had previously been reluctant to take policy action. What had proven to be so difficult to achieve in almost thirty years of history of European cooperation in education became possible in less than a year. Indeed, the European Commission managed to implement a series of mobility exchange programmes without encountering strong resistance from Member States. These programmes - among which were Comett for university-industry cooperation and Erasmus for student mobility exchange - represented a real change of pace and approach in the Community actions for education as they were created with a binding legal basis and financial and organisational resources that bore no resemblance to what had previously prevailed (Pépin 2006).

The framing of education within an economic dimension also attracted new actors, among them the European Round Table of Industrialists (henceforth, ERT), founded in 1983 and comprising CEOs from Europe's most important multinational companies, including Volvo, Nestlé, Renault, Thyssen, St. Gobain, Olivetti and Philips (ERT 2010, 151-159). Indeed, large European companies realised that education could help accompany the restructuring of European economies, improve Europe's economic competitiveness with the US and Japan, and finally, increase the quality of the preparation of the workforce, while also ensuring adhesion to Europe's values and economic goals (Green Cowles 1995; Van Apeldoorn 2002). At the centre of their analysis was the concept of knowledge policies strictly associated with the goal of strengthening the competitiveness of the EU's economic system. In 1987, the ERT set up a working group on education. In the preface to the ERT's first report, Kari Kairamo (CEO of Nokia since 1977 and ERT member) asked: "Does our educational system properly prepare people to live and work in Europe in the $21^{\text {st }}$ century and does it provide people with adequate knowledge 
throughout their working life? [...] Education is a strategic issue in European competitiveness" (Kairamo $1989,1)$. The document, which presented exhaustive facts and figures concerning the state of the art in Europe for higher, vocational, adult and primary education, claimed that "inappropriate or outdated education that has not adapted to changes in technology and restructuring of work" was the reason for the increase in unemployment in Europe (Kairamo 1989, 2-7). Therefore, in order to "revitalise" education and avoid the fall "of the technological leadership of the West", the report recommended that cooperation with business be strengthened, lifelong learning be adopted in order to upgrade the skills of older workers, primary education be improved with new tools for computer-aided instruction, and the role of mathematics and science be increased in school curricula (Kairamo 1989).

Within the same storyline as the ERT report, another publication drew attention to the problematic situation of education and training systems in Europe. In November 1990, the Industrial Research and Development Advisory Committee (henceforth, IRDAC) - a body constituted in 1989 and composed of senior industrialists, chaired by Sir Robert Telford of the UK Marconi Company, and appointed by the Commission to advise on issues related to research and development policies (Field 1988) - published a report on the "Skills Shortage in Europe" (IRDAC 1991). The opening passage of the report was quite straightforward; it stated that the "competitive position of Europe was lacking" and "might fail to produce the expected economic benefits" because of the "lack of qualified people", and that skill shortages were so serious that "immediate action is required from all parties concerned" (IRDAC 1991, 2). With several figures and forecasts on the changing demands for labour, skills and qualifications, the report claimed that there would be a constant undermining of Europe's competitive position unless immediate action was taken in terms of a huge investment in upgrading the workforce. Moreover, the report called for a "coherent European approach" with the development of "consistent and comparable approaches" regarding data collection and forecasting (IRDAC 1991, 3).

Following the emergence of education as a factor of economic growth, the 1990s became characterised by the construction of a powerful narrative in which the idea of education as a solution to Europe's lack of competitiveness was reinforced. Between 1991 and 1997, the European Commission published several reports that shared a common "discourse of crisis" constructed around several risks and challenges associated with Europe's economic outlook. The key element of their policy narrative was an economic logic according to which the role of education was to prepare "qualified human resources to respond to economic challenges and technological mutations" (Novoa 2000, 40). For instance, in the opening of the 
Memorandum on Higher Education, the European Commission underlined the "strategic importance of the higher education systems in helping to make the completed internal market work" (CEC 1991a, 1). The Memorandum maintained that a European dimension in higher education was perceived as an "economic necessity" and that there was an urgent need to create "European education to match the 'European' expectations of graduates" (CEC 1991a, 41). In its conclusions, the Memorandum proposed some solutions to tackle the challenges: strong partnerships between higher education and industry; the upgrading of the skills of the workforce through continuous education; the improvement of open and distance education; and finally, the Commission itself was identified as the actor that could act as a "catalyst and a facilitator of cooperative and common action" (CEC 1991a, 41). In a similar vein, the Memorandum on Open and Distance Learning (CEC 1991b) and the Memorandum on Vocational Training (CEC 1992) both stated that Europe was entering an extremely critical period of global competition and, unless measures and actions could be implemented to improve the skills and knowledge of the labour force, the European economy could not compete with other developed economies such as the US and Japan. Interestingly, the Memorandum on Higher Education and the Memorandum on Open and Distance Education contained several cross-references to and citations of the IRDAC report. This suggests a relationship between the European Commission's official discourse and its validation by business actors. Perhaps not by accident, the Memorandum on Higher Education was published in parallel with the IRDAC report.

The publication of these Memoranda, along with the development of a wide range of exchange programmes, was a clear sign of an increase in the European Union's interest in the field of education. As maintained by Field $(1998,53)$, the reaction to these Memoranda was quite positive. National ministries, trade unions and professional associations welcomed the potential role of the EU in determining education and training policies. The time was ripe for the formal acknowledgement of European education policy. This occurred with Article 126 of Chapter 3 of the Maastricht Treaty, in which the EU acquired a clearly specified responsibility for education. Even though Article 126 clearly stated the independence of national education policies, arguing that education and training systems, and the content of learning programmes were the responsibility of Member States, it nevertheless emphasised that "the Community shall contribute to the development of quality education by encouraging cooperation between Member States" (Barnard 1992). In line with the discourse promoted by the IRDAC and ERT publications, the general aim of European education policies became that of contributing to 
"quality education", equipping the workforce with the competences that would enable them to respond to the need for European companies to be competitive (Mitchell 1997).

The policy narrative advanced by the European Commission and European business was not just a European one, but it was interrelated with significant debates that had emerged since the mid-1980s on the impact of globalization on education. Thus, embedded within an ideological backdrop based on neoliberalism as a "normative approach to economic life" (Thiemeyer 2013, 86), ideas such as modernisation, efficiency, information technology and investment in a new knowledge-based economy were part and parcel of a discourse which was considering education as a precondition for economic growth (OECD Observer 1990, 29). As noted by Apple, "concerns for efficiency, productivity and human capital have nearly evacuated all other questions about what purposes education, in general, and schooling, in particular, should serve" (Apple 1992, 127). Moreover, demographic developments and the rise of precarious forms of work required a boost in workers' participation in the labour market. European countries, including the UK, France and the Netherlands, began to focus less on the social needs of education and became more oriented towards pursuing concepts such as the efficiency and modernisation of their education systems (Neave 1988). In addition, the policy debate which was taking place in Europe coincided with the growth of Japanese and US employment- and information-intensive sectors, with the strong performance of these countries relating to their efficient education systems (Husen et al. 1992, 7). Ineffective education systems had led to mass education and a reduction in quality, putting at risk - to echo the title of the eminent 1983 US report, A Nation at Risk - nations and their competitiveness (Gardner 1983). Hence, economic considerations of the role of education in contributing to growth and competitiveness at European level reflected - and were mutually inspired by - a cross-national consensus on the importance of "knowledge" and human capital to generate long-term growth (Cohen and Soto 2007, 52).

Almost a decade later, the emphasis on the contribution of education to economic prosperity will become an inherent corollary of the PISA OECD assessment, with "quality interpreted in economic terms as a proxy for human-knowledge capital” (Auld et al., 2019 : 198). In this respect, the OECD has fully codified this corollary through its organizational discourse and its role as agenda-setter in education (Dostal, 2004). Doing a comparison between the policy narrative of the European Commission and the one of the OECD would go beyond the scope and time-period of this paper; however PISA can be considered an example of how benchmarking and indicators of educational quality are embedded within 
neoliberal policies emphasizing "privatisation, competition, performance management and forms of accountability" (Grey and Morris, $2018: 110)$.

After the Treaty of Maastricht, the European Commission continued to take "ownership" of the problem of education. Several policy reports were published, including the Green Paper on the European Dimension of Education (CEC 1993a), the Delors White Paper on Growth, Competitiveness and Employment (CEC 1993b), the White Paper on Teaching and Learning: Towards the Learning Society (CEC 1995) and Communication Towards a Europe of Knowledge (CEC 1997). They all concerned the challenge of globalisation and its impact on the competitiveness of the European economy, putting the focus on a knowledge society and lifelong learning, the role of ICT in promoting employment, and improving the link between schools and industry, thus enabling the European Union to recover and maintain its role on the global scene (CEC 1996). In this context, the Delors White Paper on Growth, Competitiveness and Employment was one of the most significant of these documents as it contained a critical diagnosis of the weaknesses of education and training systems in Member States. This White Paper blamed the failure of education for Europe's lack of economic performance, including: the lack of skills in science and technology; the "lack of a genuine European market in skills and occupations"; "the lack of mutual transparency and the limited recognition of qualifications and skills at Community level"; and "the lack of a genuine European area for open and distance learning" (CEC 1993b, 119). To improve this catastrophic scenario, Member States were called upon to make drastic changes to their education systems and lifelong learning - intended as the ability to adapt to the changing conditions of the labour markets - emphasising their primary importance in terms of promoting employment and growth. The fears and dangers associated with the globalisation processes were the leitmotiv of the Communication Towards a Europe of Knowledge (CEC 1997): the fear related to the loss of an IT production base, and the danger referred to losing the "European identity". To avoid the risk of a "rift in society", the solution proposed was that "everything must be done to build that Europe of knowledge that we need in order to face the $21^{\text {st }}$ century" (CEC 1997, 2). In other words, economic competitiveness could only be achieved if education systems began to produce and disseminate quality education (CEC 1997, 1).

Another perceived danger was the lack of information technology skills among European students. In 1996, the Commission issued a Communication on "Learning in the information society - action plan for a European education initiative (1996-1998)". The focus of this Communication was on the importance of open access to information technology for all students and pupils in a more inclusive way; 
it stated that, without this, "Europe will pay a high price for increasingly inequitable access to these new practices" (CEC 1996, 6). Once again, the issue of competitiveness was the main reason for improving access for all to ICT; the Communication declared that "if this opportunity is missed, our increased dependence on pedagogical and cultural content originating from its main competitors outside Europe would be particularly damaging for the cultural identity and linguistic diversity of the Community" (CEC 1996, 6). Finally, the White Paper on Teaching and Learning (CEC 1995) strongly emphasised the need to work towards bringing schools and the business sector closer together as well as the importance of encouraging the attainment of new knowledge.

In essence, the education=European competitiveness frame clearly favoured the European Commission in taking ownership of European education policy, and the economic logic of this problem definition mobilised business groups and provided them with justification for having a greater say in the educational debate.

\section{Conclusion}

Despite a growing acknowledgment of the importance of supranational coordination through policy ideas, norms and standards in the comparative education literature (see also Powell, 2020), limited attention has been devoted to how specific ideas on education emerged at European level. This paper not only complements existing studies but also adds new knowledge on the mechanisms through which the European Commission was successful in constructing its policy agenda on education.

The empirical analysis seems to indicate that the concept of "competitiveness" with reference to education had already emerged well before the Lisbon "mantra", playing a significant role in the policy debate since the mid-1980s. As mentioned in the introduction to this paper, the role of the European Commission in the formulation of a policy agenda on European education has remarkably increased since the Lisbon Strategy of 2000. However, by process tracing the developments which occurred in European education policy from 1975 to 1997 through primary sources, original archival materials and secondary sources, this paper has traced a clear and sequential pathway from ideational origins to policy outcomes constructed around a specific problem definition of education, which then ended with its institutional anchoring in 2000. Proposals such as the contribution of education to Europe's economic competitiveness, the need to have a highly skilled and mobile workforce, and the importance of investing in human capital as a prerequisite for growth were all ideas that had arisen during the mid-1980s. The 
same ideas became articulated over the course of the 1990s through the incremental construction of a policy narrative that pointed to education as the solution to Europe's lack of competitiveness, which in turn was institutionalised under the umbrella concept of the "knowledge economy" launched by the Lisbon Strategy of 2000. Hence, the paper casts the existing literature examining the recent emergence of European education policy in a new light as it provides an original perspective that extends the analysis to the process which prefigured the changes that took place since implementation of the Lisbon Strategy.

According to this paper's theoretical argument, a variety of factors are important in successfully defining a problem: (i) the power of those advocating the problem definition; (ii) the ability to frame an issue through rhetorical strategies; and (iii) the fit between the problem and the broader political and economic climate of the times.

Emerging in the mid-1970s as an autonomous policy domain at European level - through the creation of a Directorate in the first 'Action Programme on Education' of 197, European education policy was characterised by a policy orientation encompassing different economic, social, and cultural themes. In this respect, the European dimension of education was intended under its double dimension of mobility and knowledge of the history of Europe among citizens. It was in the mid-1980s that the problem definition of education as a factor of Europe's economic growth came to the fore. On the one hand, under the altered material conditions at the beginning of the 1980s, namely unemployment and technological change, new concerns regarding the competitiveness gap with the US and the need to provide European companies with a highly skilled workforce able to compete with the US and Japanese economies became prominent. The Delors Presidency, including the appointment of Peter Sutherland as Commissioner for Education, represented a shift in the policy orientation of education. During the 1990s, the economic dimension of education was reinforced with the European Commission and business actors taking further ownership of the problem. Epistemic communities such as business interest groups - namely, the IRDAC and ERT - acted as ideas carriers by pushing forward and advocating their favourite definition of education, conceived as a tool to provide the workforce with the competences required to meet the competitiveness needs of European firms within the Single Market project. In this respect, the empirical analysis has provided evidence of the European Commission establishing not only operational leadership thanks to its organisational structure and resources, but also moral authority in articulating a common European problem to be solved through specific solutions. 
Through the publication of several Memoranda, Green Papers and White Papers, the European Commission rhetorically constructed a "discourse of crisis" through a selective interpretation of education framed as a solution to Europe's lack of competitiveness. The analysis of these documents has also shed light on the rhetorical strategies used to frame the policy narrative, for instance counting, storytelling, and naming and blaming, that, by functioning as 'attention' mechanisms, were shifting the attention towards themes such as quality of education, the need for investing in a highly skilled and mobile workforce, investment in lifelong learning, and cooperation between education institutions and business. Thus, the European Commission was successful in establishing a powerful "masterframe" through selecting and aggregating a set of existing ideas that contained a specific diagnosis, by identifying problems and attributing responsibility, and a prognosis, by proposing specific policy solutions.

Furthermore, the education=European competitiveness frame was also consistent with the prevailing zeitgeist of the mid-1980s/mid-1990s. On the one hand, it was part and parcel of the Single Market project, with education (or human capital) framed as a "common" European resource that could have addressed the needs of European companies and contributed to the formation of a highly skilled and mobile workforce (as for instance mentioned in the three Commission Memoranda). On the other, it was anchored to the advancement of neo-liberal ideas of the human capital approach, under the assumption of a relationship between quality of education and efficiency of the economy. In sum, an explanation of why specific ideas about education were successful cannot be completely separated from the broader social, economic and cultural context in which they were advocated.

\section{Acknowledgements}

The authors would like to thank two anonymous reviewers for their helpful comments on earlier versions

of this article. The work on the manuscript was supported by the Economic and Social Research Council (ESRC), grant number ES/S011005/1. 


\section{Disclosure Statement}

No potential conflict of interest was reported by the authors.

\section{Notes on contributor}

Marina Cino Pagliarello is Fellow in European Politics and Public Policy at the European Institute of the London School of Economics where she also earned her $\mathrm{PhD}$ with a thesis entitled "Constructing the Europe of Knowledge? The role of ideas in the transformations of European education policy (19752010)". Her research interests include European political economy, public policy, Europeanisation and the politics of education. She is specifically interested in understanding the role of political and economic actors in shaping public policies and the mechanisms through which ideas play a role in the emergence of new problem definitions and in restructuring actors' interests.

\section{References}

Agence Europe. 1985. N. 4111. 18 June 1985.

Apple, M.W. 1992. "Reviewed Work: Education and the Economy in a Changing Society by The Organization for Economic Cooperation and Development". Comparative Education Review. 36 (1) (Special Issue on Education in a Changing Europe, Feb. 1992), pp. 127-129.

Auld, E. and Morris, P. 2016. "PISA, policy and persuasion: translating complex conditions into education 'best practice". Comparative Education, 52:2, 202-229.

Auld, E; Rappleye J.; and Morris P. 2019. "PISA for Development: how the OECD and World Bank shaped education governance post-2015”. Comparative Education, 55:2, 197-219.

Bachrach, P., and M. Baratz. 1962. “Two Faces of Power.” American Political Science Review 56: $947-952$.

Barnard, C. 1992. "The Maastricht agreement and education, one step forward two steps back", Education and the Law. 4, pp. 123-124.

Bartolini, S. 2005. Restructuring Europe. Oxford: Oxford University Press.

Baumgartner, F.R. 2007. "EU Lobbying: a View from the US.” Journal of European Public Policy 14, April: $482-488$.

Beland, D. and Cox, R.H. 2016. "Ideas as coalition magnets: coalition building, policy entrepreneurs, and power relations", Journal of European Public Policy, 23: 3, pp. 428-445.

Bennett A., and J.T. Checkel. 2014. Process Tracing in the Social Sciences: From Metaphor to Analytic Tool. Forthcoming with Cambridge University Press.

Beukel, E. 1994. "Reconstructing Integration Theory: The Case of Educational Policy in the EC." Cooperation and Conflict 29 (1): 33-54, 35, 37-38. 
Borras, S. 2009. "The Politics of the Lisbon Strategy: The Changing Role of the Commission." West European Politics 32: $97-118$.

Chou, M.-H. and A. Gornitzka. (Eds.). (2014). Building the knowledge economy in Europe: New constellations in European research and higher education governance. Cheltenham: Edward Elgar.

Cobb, R.W., and C.D. Elder. 1972. Participation in American Politics: The Dynamics of Agenda Building. Boston: Allyn and Bacon.

Cohen, D. and Soto, M. 2007. "Growth and human capital: Good data, good results". Journal of Economic Growth. 12 (1), pp. 51-76.

Commission of the European Communities (CEC).1974. Education in the European Community. COM (74)253 final/2, Communication from the Commission to the Council, presented on 11 March 1974.

Commission of the European Communities (CEC). Making a Success of the Single Act: A New Frontier for Europe. Communication from the Commission to the Council. COM. (1987) 100. Brussels, 1987.

Commission of the European Communities (CEC). 1991a. Memorandum on Higher Education in the European Community (Brussels, Task Force on Human Resources, Education, Training, Youth).

Commission of the European Communities (CEC). 1991b. Memorandum on Open and Distance Learning in the European Community (Brussels, Task Force on Human Resources, Education, Training, Youth.

Commission of the European Communities (CEC). 1992. Memorandum on Vocational Training in the European Community in the 1990s. Luxembourg, OOPEC.

Commission of the European Communities (CEC). 1993a. "Green Paper on the European Dimension of Education." COM (93) 457/final, Brussels, 29 September 1993.

Commission of the European Communities (CEC). 1993b. "White paper on Growth. Competitiveness and Employment" COM (93) 700 final.

Commission of the European Communities (CEC). 1995. "White Paper on Education and Training - Teaching and Learning - Towards the Learning Society.” COM (95) 590/final, Brussels, 29 November 1995.

Commission of the European Communities (CEC). 1996. "Learning in the Information Society - Action Plan for a European Education Initiative (1996-1998).” COM (96) 471/final, Brussels, 2 October 1996.

Commission of the European Communities (CEC). 1997. "Towards a Europe of Knowledge." COM (97) 563/final, Communication to the Council, the European Parliament, the Economic and Social Committee and the Committee of the Regions, Office for Official Publications of the European Communities, Luxembourg, 11 November 1997.

Council. 1976. Resolution of the Council and of Ministers meeting within the Council of 9 February 1976 comprising an action programme in the field of education.

Corbett, A. 2005. Universities and the Europe of Knowledge: Ideas, Institutions and Policy Entrepreneurship in European Union Higher Education Policy, 1955-2005. London: Palgrave Macmillan.

Cusumano, M.A. 1985. The Japanese Automobile Industry: Technology and Management at Nissan and Toyota. Cambridge, Mass.: Harvard University Press.

Daviter, F. 2007. "Policy Framing in the European Union.” Journal of European Public Policy 14 (4): 654-666. 
De Wit, K., and J.C. Verhoeven. 2001. "Higher Education Policy of the European Union: With or Against the Member States?" In Higher Education and the Nation State, edited by J. Huisman, P. Maassen and G. Neave, 175-231. Amsterdam: Pergamon Press.

Dostal, M. J. (2004) Campaigning on expertise: how the OECD framed EU welfare and labour market policies - and why success could trigger failure, Journal of European Public Policy, 11:3, 440-460.

Dryzek, J. 1993. "Policy Analysis and Planning: From Science to Argument." In The Argumentative Turn in Policy Analysis and Planning, edited by F. Fischer and J. Forester. London: Duke University Press.

ERT. 2010. European Round Table of Industrialists: Highlights 1983-2010. Brussels: European Round Table of Industrialists.

Ertl, H. 2003. "The European Union and Education and Training: An Overview of Policies and Initiatives." In Implementing European Union Education and Training Policy: A Comparative Study of Issues in Four Member States, edited by David Phillips and Hubert Ertl, 13-39. Dordrecht: Kluwer Academic.

European Commission. 1989. Communication of the Commission to the Council: General Guidelines for Vocational Training 1989-1992. COM (89) 236 final, 2 June 1989, Luxembourg.

European Council. 2000. Conclusions at the Lisbon Summit. March 23-24, 2000.

Felstiner, W.L.F., R.L. Abel, and A. Sarat. 1980-1981. "The Emergence and Transformation of Disputes: Naming, Blaming, and Claiming." Law and Society Review 15: 631-644.

Field, J. 1998. European Dimensions: Education, Training and the European Union. London: JKP.

Fischer, F. 2003. Reframing Public Policy: Discursive Politics and Deliberative Practices. Oxford: Oxford University Press.

Fitoussi, J.-P., Phelps, E.S. and Sachs, J. 1986. "Causes of the 1980s Slump in Europ', Brookings Papers on Economic Activity. 2, pp. 487-520.

Gardner, D.P. 1983. A Nation at risk: the imperative for educational reform. Washington, D.C.: United States Department of Education.

Goldstein, J. 1993. Ideas, Interests and American Trade Policy. Ithaca, NY: Cornell University Press.

Gornitzka, Å. 2005. The Open Method of Coordination as Practice: A Watershed in European Education Policy? Arena: Center of European Studies, Working Paper No16, University of Oslo.

Green Cowles, M. 1995. "Setting the Agenda for a New Europe: The ERT and EC 1992." Journal of Common Market Studies 33 (4): 503-504.

Grek, S.; Lawn, M.; Ozga, J.; Segerholm, C. 2013. "Governing by inspection? European inspectorates and the creation of a European education policy space", Comparative Education, 49:4, 486-502

Grey, S. and Morris, P. 2018. “PISA: multiple 'truths' and mediatised global governance,”. Comparative Education, 54:2, 109-131.

Haas, P. 1992. "Introduction: Epistemic Communities and International Policy Coordination." International Organization $46(1): 1-35$.

Holford, J. and M. Špolar, V. 2012. "Neoliberal and inclusive themes in European lifelong learning policy". In: Riddell, S., Markowitsch, J. and Weedon, J. (eds.) Lifelong learning in Europe: equity and efficiency in the balance. Bristol: Policy Press, pp. 39-61. 
Husen, T., Tuijnam, A. and Halls, W.D. 1992. Schooling in Modern European Society. Oxford: Pergamon Press.

IRDAC. 1991. Skills Shortages in Europe. Brussels, Industrial Research and Development Advisory Committee of the Commission of the European Community.

Janne, H. 1973. "For a Community Policy on Education". Bulletin of the European Communities. Supplement 10/73, Luxembourg: pp. 1-60.

Jakobi, A.P., K. Martens, and C.D. Wolf, eds. 2010. Education in Political Science: Discovering a Neglected Field. London: Routledge.

Jones H.C. 1983. "Education in the European Community". North of England Educational Conference, Liverpool, 5-7 January 1983.

Kairamo, K. 1989. Education for Life: A European Strategy. London and others: Butterworths.

Kingdon, J.W. 1984. Agendas, Alternatives and Public Policies. Boston: Little Brown.

Lawn, M., and A. Novoa. 2002. Fabricating Europe - The Formation of an Education Space. London: Kluwer.

Leitner, H. 1997. "Reconfiguring the Spatiality of Power: The Construction of a Supranational Migration Framework for the European Union." Political Geography 16 (2): 123-143.

Lukes, S. 1974. Power: A Radical View. London: Macmillan Press.

Mehta, J. .2011. "The Varied Roles of Ideas in Politics: From 'Whether' to 'How'.” In Ideas and Politics in Social Science Research, edited by D. Béland and R.H. Cox, 23-46. Oxford; New York: Oxford University Press.

Milward, A. 1992. The European Rescue of the Nation State. London: Routledge.

Mitchell, I. 1997. "European Union Cooperation in Higher Education and Training: New Challenges and Recent Progresses." Vocational Training European Journal n. 2.

Mucciaroni, G. 1992. “The Garbage-Can Model and the Study of Policymaking: A Critique.” Polity 24: 459-482.

Neave, G. 1988. “On the Cultivation of Quality, Efficiency and Enterprise: An Overview of Recent Trends in Higher Education in Western Europe, 1986-1988.” European Journal of Education 23 (1-2): 7-23.

Novoa, A. 2000. "The restructuring of the European Educational Space”. In: Popkewitz, T. (ed.) Educational Knowledge - Changing Relationships between the State, Civil Society, and the Educational Community. New York: SUNY Press, pp. 31-57.

OECD Observer. 1990. Issue 3. Paris : OECD.

Patterson, M., and K. Monroe. 1998. "Narrative in Political Science.” Annual Review of Political Science 315-331.

Pépin, L. 2006. The History of European Cooperation in Education and Training. Europe in the Making - an example. European Commission, Office for Official Publications of the European Communities.

Powell, J. W. 2020. "Comparative education in an age of competition and collaboration", Comparative Education, 56:1, 57-78.

Princen, S. 2011. “Agenda-Setting Strategies in EU Policy Processes.” Journal of European Public Policy 18:7: 927943. 
Rasmussen, M., and A.C. Knudsen. 2009. The Road to a United Europe. Interpretations of the Process of European Integration. Brussels: Peter Lang.

Rein, M., and D.A. Schön. 1993. "Reframing Policy Discourse." In The Argumentative Turn in Policy Analysis and Planning, edited by Frank Fischer and John Forester, 145-166. Durham, NC: Duke University Press.

Rhinard, M. 2010. Framing Europe: The Policy-Shaping Strategies of the European Commission. Dordrecht: Republic of Letters.

Rochefort, D.A., and R.W. Cobb, eds. 1994. The Politics of Problem Definition. Lawrence, KS: University Press of Kansas.

Rosamond, B. 1999. Theories of European Integration. Basingstoke: Palgrave Macmillan.

Schattschneider, E.E. 1960. The Semi-Sovereign People. A Realist's Guide to Democracy in America. New York: Holt, Rinehart and Winston.

Schmidt, V.A., and M. Thatcher. 2013. Resilient Liberalism in Europe's Political Economy. Cambridge: Cambridge University Press.

Stone, D. 2002. Policy Paradox. New York: Norton and Company.

Sutherland, P. 1985a. Introductory remarks by Mr Peter Sutherland at the meeting with social partners in Val Duchesse. 31 January 1985. Historical Archives of the European Union-PSP-171.

Sutherland, P. 1985b. "Priority of education in Community policy". Mr Peter Sutherland's speech on education policy in the Community addressed to the meeting of the European Parliament Committee on youth, culture, education, information and sport on the 25th of April 1985. Historical Archives of the European Union-PSP-196.

Sutherland, P. 1985c. Weekend of reflection - Villers-le-Temple. Preparatory note for Sutherland on the Social Fund. 31 May 1985.Historical Archives of the European Union-PSP-393.

Sutherland, P. 1985d. "Towards Stronger European Community Action in Education for the benefits of students". Speech by Commissioner Peter Sutherland at the Etats Généraux des Etudiants de l'Europel European Students' Forum. Paris, Saturday 20 April, 1985. Historical Archives of the European Union-PSP-225.

Thiemeyer, G. 2013. "Economic models in France and Germany and the debates on the Maastricht Treaty". Journal of European Integration History. Bd. 19 (1), S85-103.

Trampusch, C. 2010. "Employers, the State and the Politics of Institutional Change: Vocational Education and Training in Austria, Germany and Switzerland.” European Journal of Political Research 49: 545-573.

Van Apeldoorn, B. 2002. Transnational Capitalism and the Struggle over European Integration. London: Routledge, RIPE Studies in Global Political Economy.

Walkenhorst, H. 2008. "Explaining Change in EU Education Policy.” Journal of European Public Policy 15 (4) 567587.

Weir, M. 1992. Politics and Jobs. Princeton: Princeton University Press.

Yanow, D. 2000. Conducting Interpretative Policy Analysis. Thousand Oaks: Sage Publications.

Zahariadis, N. 2008. “Ambiguity and Choice in European Public Policy.” Journal of European Public Policy 15 (4): 514530 . 
